\title{
An Evaluation of Pickling Cucumber Varieties at Isabela Substation
}

\author{
M. Rico Ballester, César A. Ramos Caro, and J. Vélez Fortuño ${ }^{1}$
}

\section{INTRODUCTION}

Slicing cucumbers are grown in Puerto Rico on a limited scale for the local market, and for export to the New York winter market. Among the most favorable areas for this crop are Isabela, Lajas, and Ponce, consider ing climate, topography, and soil, and the fact that these areas are under irrigation.

Although pickling cucumbers are not grown at all except in a few home gardens, they have a great potential for the export trade, and for satisfying local demand, which during the fiscal year of 1960 amounted to 237,812 pounds with a value of $\$ 61,074(2)^{2}$.

One of the main hindrances to growing cucumbers in Puerto Rico is the high incidence of downy mildew, a fungous disease caused by Pseudoperonospora cubensis (Berk. \& Curt.) Rostow., which attacks the foliage, stunting growth, greatly reducing production, and eventually causing the premature death of the plant. This problem was partly solved when the Station released, in 1942, Puerto Rico 39 (3), a slicing variety highly resistant to the disease. Since then, several resistant slicing varieties have been developed in the mainland which are planted in those areas where downy mildew is prevalent.

\section{PROCEDURE}

To observe the behavior of pickling varieties of cucumber in Puerto Rico, a variety trial was established at the Isabela Substation farm on August 25, 1960. Eleven commercial pickling varieties were tested (see table 1) together with P.R. 39, which was included to serve as a check to compare downy mildew incidence among the other varieties. The experimental design used was a rectangular $(3 \times 4)$ lattice with 6 replications. Each plot comprised 2 rows 6 feet apart and 15 feet long, with an area of 180 square feet $(0.004132$ of an acre). Each row consisted of 15 hills 1 foot apart, with 1 plant per hill. Filter-press cake was applied at the rate of 40 tons per acre several days prior to planting, and 9-10-5 fertilizer was added at planting time at the rate of 750 pounds per acre.

Sprays for insects and diseases were made weekly with alternate appli-

${ }^{1}$ Assistant Horticulturist, Lajas Substation; Research Assistant in Agronomy, Isabela Substation; and Head, Genetics Department, Agricultural Experiment Station, University of Puerto Rico, Río Piedras, P.R.

2 Italic numbers in parentheses refer to Literature Cited, p. 362. 
cations of zerlate and copper-A compound, each time with parathion ${ }^{3}$. Aldrin was applied to the soil at time of harrowing.

Fruit was harvested and classified in 3-, 4-, and 5-inch sizes and culls, according to the National Pickle Packers Association (1) standards. The first picking was made on October 6 and the last on November 7, to make a total of 10 pickings.

Downy mildew appeared about the time of the first picking and increased in intensity as time passed. At the peak of the harvest, which began

TABLE 1.-Yield of 12 varieties of cucumbers at Isabela Substation farm, 1960, in hundredweights per acre of 3-, 4-, and 5-inch fruits

\begin{tabular}{|c|c|c|c|}
\hline Variety & Yield & $\begin{array}{l}\text { Superior at 1-percent } \\
\text { to }-\end{array}$ & $\begin{array}{c}\text { Superior at 5-percent } \\
\text { to }-\end{array}$ \\
\hline 1. P.R. 39 & 116.09 & $\begin{array}{c}2,3,4,5,6,7,8 \\
9,10,11,12 .\end{array}$ & $\begin{array}{c}2,3,4,5,6,7,8 \\
9,10,11,12 .\end{array}$ \\
\hline 2. Wisconsin SMR 15 & 50.65 & $8,9,10,11,12$ & $\begin{array}{l}6,7,8,9,10,11 \\
12 .\end{array}$ \\
\hline 3. Model & 50.41 & $8,9,10,11,12$ & $\begin{array}{c}6,7,8,9,10,11 \text {, } \\
12 .\end{array}$ \\
\hline 4. Ohio MR 17 & 45.03 & & $8,9,10,11,12$ \\
\hline 5. National Pickling & 36.59 & & \\
\hline 6. York State Pickling & 28.21 & & \\
\hline 7. Wisconsin SR 6 & 24.87 & & \\
\hline 8. Chicago Pickling & 20.57 & & \\
\hline 9. Everbearing & 18.58 & & \\
\hline 10. Extra Early Green Prolific & 17.44 & & \\
\hline 11. Heinz Pickling & 16.86 & & \\
\hline 12. Fordhook Pickling & 15.70 & & \\
\hline
\end{tabular}

on October 20, an appraisal of its damage was made in every plot. This appraisal is summarized in the following tabulation showing the results of two simultaneous counts and six replications:

\begin{tabular}{lr}
\multicolumn{1}{c}{ Variety } & Count \\
P.R. 39 & 4.83 \\
York State Pickling & 3.08 \\
Chicago Pickling & 3.08 \\
Wisconsin SMR 15 & 2.91 \\
Fordhook Pickling & 2.75 \\
Wisconsin SR 6 & 2.50 \\
Extra Early Green Prolific & 2.41 \\
Everbearing & 2.38 \\
Heinz Pickling & 2.38 \\
Ohio MR 17 & 2.16 \\
National Pickling & 2.08 \\
Model & 1.58
\end{tabular}

${ }^{3}$ Since then the fungicides have been substituted by maneb, zineb and nabam in cucumber spraying programs, while diazinon is being used instead of parathion during harvest. 
Mosaic, the other important cucumber disease in Puerto Rico, was not observed in any of the varieties throughout the time that the experiment lasted.

The plots were furrow-irrigated and water was applied whenever needed, as judged by soil and plant conditions. The total rainfall received by the experiment was 13.92 inches, 13.87 of which were received during September and October.

\section{EXPERIMENTAL RESULTS AND DISCUSSION}

The extraordinary superiority of P.R. 39 over the other varieties (see table 1) is attributed in part to the fact that it was bred for adaptability to our conditions and especially for resistance to downy mildew. However, P.R. 39 is a slicing-type cucumber and its probable use for pickling has yet to be studied. Were it ever to be considered for this purpose, its advantage over other varieties resistant to downy mildew would be its rather short, blocky fruit, suitable for pickling.

\section{SUMMARY}

1. Eleven pickling cucumber varieties were planted together with P.R. 39 at Isabela, P.R., on August 25, 1960.

2. The most serious disease encountered was downy mildew.

3. P.R. 39 yielded more than twice as much as Wisconsin SMR 15, the next variety in rank.

4. This yielding superiority of P.R. 39 over the other varieties is attributed to its resistance to downy mildew

\section{RESUMEN}

1. El 25 de agosto de 1960 se sembraron en Isabela once variedades de pepinillo de encurtir conjuntamente con la conocida variedad P.R. 39.

2. El añublo lanoso fué la enfermedad que más afectó a las variedades bajo prueba.

3. La variedad P.R. 39 produjo dos veces más que la Wisconsin SMR 15, que fué la segunda en producción.

4. Esta superioridad en rendimiento de la variedad P.R. 39 sobre las demás que se probaron se atribuye a su gran resistencia al añublo lanoso.

\section{LITERATURE CITED}

1. National Pickle Packers Association, n.d., Official Chart.

2. Puerto Rico Planning Board, External trade statistics, San Juan, P.R., 1960.

3. Roque, A., Biennial Report, fiscal years 1939 and 1940, Univ. of P.R. Agr. Exp. Sta., pp. 120-1, Río Piedras, P.R., 1940. 